\title{
Microstructural properties of lithium-added cement mortars subjected to alkali-silica reactions
}

\author{
ILHAMI DEMIR $^{1,2}$, ÖZER SEVIM ${ }^{1, *(\mathbb{D})}$ and ILKKER KALKAN ${ }^{1}$ \\ ${ }^{1}$ Department of Civil Engineering, Kirıkkale University, 71451 Kirikkale, Turkey \\ ${ }^{2}$ Department of Architecture, Amasya University, 05100 Amasya, Turkey \\ e-mail: ildemir@kku.edu.tr; ozersevim@kku.edu.tr; ilkerkalkan@kku.edu.tr
}

MS received 4 December 2017; revised 5 March 2018; accepted 2 April 2018; published online 22 June 2018

\begin{abstract}
Little comparative research has been done on the efficiency of lithium additives to reduce the alkali-silica reaction (ASR) expansion. To reduce the ASR effects of reactive aggregate, different mortar bars were obtained by adding lithium additives $\left(\mathrm{Li}_{2} \mathrm{SO}_{4}, \mathrm{LiNO}_{3}, \mathrm{Li}_{2} \mathrm{CO}_{3}, \mathrm{LiBr}\right.$ and $\left.\mathrm{LiF}\right)$ to the mixing water by the following mass percentages of cement: $0 \%, 0.5 \%, 1 \%, 1.5 \%, 2 \%, 2.5 \%$ and $3 \%$. The ASR expansions of the mortar bars at 2, 7 and 14 days were identified according to ASTM C 1260-14. The morphology of the specimens subject to the ASR effect was analysed using a scanning electron microscope, and their chemical composition was analysed by electron dispersion spectroscopy. Among all specimens, the lowest level of 14-day ASR expansion was obtained in mortar bars with $3 \% \mathrm{Li}_{2} \mathrm{CO}_{3}$ additive.
\end{abstract}

Keywords. Alkali-silica reaction; mortar bar; length change; lithium compounds; micro-structure.

\section{Introduction}

Alkali-silica reaction (ASR) is a reaction that occurs among aggregates containing reactive silica forms with alkali oxides, resulting from cementation. ASR creates an expansion effect on concrete. This reaction simply takes place in two stages. In the first stage, ASR gel products are formed by the combination of reactive silicas with alkalis and then, in the second stage, the formed alkali-silica gels expand in the presence of moisture in the environment at an appropriate temperature. The resulting expansion also causes cracking and deterioration of concrete over time $[1,2]$.

The damage caused by ASR in concrete was first introduced by Stanton in North America in 1940 as a case and has been known in many countries since then [3, 4]. A lot of studies have been published since Stanton, but the ASR mechanism has not been understood with all the details yet [5-8].

The product of the reaction of alkali-silica is a silica gel that holds water [9]. The most common minerals with silica in their composition are quartz, tridymite, cristobalite and opal groups [10]. With the inclusion of moisture in the alkali-silica gel, the expansion of concrete can reach up to $2-3 \%$ by volume. The stresses in unreinforced mass concrete associated with this expansion might exceed the tensile strength of concrete, which in turn might cause fractures and cracks throughout the volume and on the

*For correspondence surface of the concrete mass. Because ASR is a reaction that occurs in concrete and causes expansion, map-like cracks constitute the only visible external sign of ASR [11].

The use of mineral admixtures improves the compressive strength, permeability and void structure of mortar and concrete over time [12]. The total void ratio of concrete or mortar is reduced thanks to the hydration process associated with the mineral additives [13]. Mineral admixtures such as silica fume and fly ash are also known to reduce ASR expansions $[14,15]$. Pozzolans are also commonly preferred in concrete mixtures for the same purpose. Pozzolans maintain the lime of the cement mortar and reduce the $\mathrm{pH}$ value of the environment. Moreover, they decrease the solubility of the silica and prevent ASR and gel formation. Another benefit of pozzolans for ASR is that they increase the impermeability of concrete or mortar [16]. Various studies have been conducted in an effort to reduce ASR by using different mineral additives in the mixture. A recent study reported that fly ash reduces the expansion of ASR [17].

Lithium-containing additives constitute a commonly preferred type of additive for reducing ASR. Chemical salts containing lithium salts are highly effective in reducing the expansion of mortars liable to ASR. These salts are generally added to the concrete mixture against the potential of reactivity of aggregates [18]. Although the effects of lithium additives on the reduction of ASR expansion have been subject to a number of studies in the past [19-21], the mechanism of this reduction has not been clarified yet. 
Previous methods for ASR prevention usually focused on either directly hindering ASR or changing the chemical environment and abstaining from reactive aggregates using low-alkali cement and using mineral additives or lithium involving additives [22, 23]. Many studies indicated that using lithium additives at proper dosages reduces concrete expansion caused by ASR [24-27], while some percentages of $\mathrm{Li}_{2} \mathrm{CO}_{3}$ and $\mathrm{LiOH}$ increase the expansion of ASR [28, 29].

There is a clear need in the literature for studies not only to explain the effectiveness of lithium compounds in avoiding ASR, but also to determine the influence of the time and strength of cement on the effects of lithium compounds on ASR expansion [30]. The efficacy of lithium additives to reduce expansion associated with ASR in concrete is widely accepted. Nevertheless, the number of studies that comparatively examine the efficacy of lithium additives to reduce the ASR expansion is far too limited.

The aim of the present study is to determine the effects of various lithium additives on ASR expansion and their micro-structural properties. To this end, five types of lithium additives $\left(\mathrm{Li}_{2} \mathrm{SO}_{4}, \mathrm{LiNO}_{3}, \mathrm{Li}_{2} \mathrm{CO}_{3}, \mathrm{LiBr}\right.$ and $\left.\mathrm{LiF}\right)$ were added to the mixing water by $0.5 \%, 1 \%, 1.5 \%, 2 \%$, $2.5 \%$ and $3 \%$ in mass ratio of the cement, and mortar specimens were prepared. The mortar bars, the mixing water with the specified lithium additives, were exposed to ASR for 14 days, and the length changes were recorded. In this way, linear length changes of cement mortars that have been impressed by ASR were compared. Additionally, the micro-structural properties of cement mortars affected by ASR were analysed using a scanning electron microscope.

\section{Materials and method}

\subsection{Materials}

In this study, five different kinds of lithium additives: $\mathrm{LiNO}_{3}$ (lithium nitrate), $\mathrm{Li}_{2} \mathrm{CO}_{3}$ (lithium carbonate), $\mathrm{Li}_{2}$ $\mathrm{SO}_{4}$ (lithium sulphate), $\mathrm{LiBr}$ (lithium bromide) and $\mathrm{LiF}$ (lithium fluoride), each with purity levels higher than $98 \%$, were used. To examine the ASR effect of using these lithium additives in the study, natural aggregate, collected from Çoruh River in the Artvin province of Turkey, was used in the study. The chemical analysis of the aggregates, mineralogical properties and grading of the natural aggregate used in this study can be found in tables 1 and 2, respectively. Chemical properties of the aggregates were determined by X-ray fluorescence spectrometry (XRF). Mineralogical properties of the aggregates were measured via EDTA, supplemented by X-ray diffraction (XRD) analyses.

The chemical and physical properties of CEM I $42.5 \mathrm{R}$ cement, presented in table 3 , were used. Chemical properties of the cement were determined by XRF. Alkali concentration in each cement sample is typically expressed as
Table 1. The chemical and mineralogical properties of the natural aggregate.

\begin{tabular}{lcccr}
\hline \multicolumn{2}{l}{ Chemical properties } & & \multicolumn{2}{c}{ Mineralogical properties } \\
\cline { 5 - 5 } Compound & $\%$ & & Compound & $\%$ \\
\hline $\mathrm{SiO}_{2}$ & 65.53 & & Quartz & 42.68 \\
$\mathrm{CaO}$ & 19.20 & & Muscovite & 28.67 \\
$\mathrm{Fe}_{2} \mathrm{O}_{3}$ & 6.30 & & Albite & 12.38 \\
$\mathrm{Al}_{2} \mathrm{O}_{3}$ & 5.50 & & Anorthite & 9.30 \\
$\mathrm{~K}_{2} \mathrm{O}$ & 2.55 & & Calcite & 4.71 \\
$\mathrm{TiO}_{2}$ & 0.62 & & Chlorite & 2.09 \\
$\mathrm{BaO}_{\mathrm{MnO}}$ & 0.2 & & Dolomite & 0.17 \\
$\mathrm{Tm}_{2} \mathrm{O}_{3}$ & 0.1 & & & \\
$\mathrm{SrO}^{\mathrm{Rb}}$ & 0.1 & & & \\
\hline
\end{tabular}

Table 2. The grading of the natural aggregate used in this study.

\begin{tabular}{lc}
\hline Sieve size & Amount $(\%)$ \\
\hline $4.75 \mathrm{~mm}($ No: 4$)-2.36 \mathrm{~mm}($ No: 8$)$ & 10 \\
$2.36 \mathrm{~mm}($ No: 8$)-1.18 \mathrm{~mm}($ No: 16$)$ & 25 \\
$1.18 \mathrm{~mm}($ No: 16$)-600 \mu \mathrm{m}$ (No: 30) & 25 \\
$600 \mu \mathrm{m}$ (No: 30)-300 $\mu \mathrm{m}$ (No: 50) & 25 \\
$300 \mu \mathrm{m}$ (No: 50$)-150 \mu \mathrm{m}$ (No: 100$)$ & 15 \\
\hline
\end{tabular}

Table 3. Chemical and physical properties of Portland cement.

\begin{tabular}{|c|c|}
\hline & CEM I $42.5 \mathrm{I}$ \\
\hline \multicolumn{2}{|l|}{ Chemical compound } \\
\hline $\mathrm{CaO}(\%)$ & 62.18 \\
\hline $\mathrm{SiO}_{2}(\%)$ & 21.11 \\
\hline $\mathrm{Al}_{2} \mathrm{O}_{3}(\%)$ & 5.38 \\
\hline $\mathrm{Fe}_{2} \mathrm{O}_{3}(\%)$ & 3.22 \\
\hline $\mathrm{SO}_{3}(\%)$ & 3.1 \\
\hline $\mathrm{MgO}(\%)$ & 1.99 \\
\hline $\mathrm{K}_{2} \mathrm{O}(\%)$ & 0.79 \\
\hline $\mathrm{Na}_{2} \mathrm{O}(\%)$ & 0.38 \\
\hline \multicolumn{2}{|l|}{ Physical properties } \\
\hline Specific gravity & 3.17 \\
\hline Blaine fineness $\left(\mathrm{cm}^{2} / \mathrm{g}\right)$ & 3342 \\
\hline Initial set (min) & 150 \\
\hline Final set (min) & 195 \\
\hline $\mathrm{Na}_{2} \mathrm{O}+0.658 \mathrm{~K}_{2} \mathrm{O}$ & 0.90 \\
\hline Loss of ignition (\%) & 2.38 \\
\hline Volumetric expansion (mm) & 1.75 \\
\hline
\end{tabular}

alkali equivalent $\left(\mathrm{Na}_{2} \mathrm{O} e q\right)$ that is defined as $\% \mathrm{Na}_{2}$ $\mathrm{O}+0.658 \times \% \mathrm{~K}_{2} \mathrm{O}$. This alkali equivalent value is given in table 3 . 


\subsection{Method}

2.2a Preparation of specimens: The possible harmful effects of active silica on concrete aggregates are determined based on ASTM C 1260-14 mortar bar experiments [31]. This method enhances the curing conditions, accelerating the reaction, which allows the assessment of the reactivity of the aggregates in 16 days. Aggregate 2.25 $(990 \mathrm{~g})$ times as heavy as cement at grading, described by ASTM C 1260-14 standard, and mortar mixture with 0.47 water $(206.8 \mathrm{~g}) /$ cement $(440 \mathrm{~g})$ ratio were prepared. Mortar samples were placed into $25 \times 25 \times 285 \mathrm{~mm}^{3}$ (width $\times$ height $\times$ length) prismatic moulds. They were demoulded after $24 \mathrm{~h}$ and their first lengths were measured. For a period of one day following the demoulding, the samples were kept in pure water at $80^{\circ} \mathrm{C}$, and their lengths were measured. For a period of 14 days that follows, they were preserved at $80^{\circ} \mathrm{C}$ in $1 \mathrm{M} \mathrm{NaOH}(900 \mathrm{ml}$ pure water $40 \mathrm{~g}$ sodium hydroxide) solution, and their lengths were measured periodically.

Mortar bar samples were prepared at different portions for microstructure analysis. The most suitable surface and sizes were selected among these samples. For the microstructure surface examination, sputter coater gold coating was applied to these specimens. XRD, energy dispersive spectroscopy (EDS) and scanning electron microscopy (SEM) were used for the microstructure analysis. EDS analyses were implemented at $35 \times$ magnification.

\section{Results and discussion}

\subsection{The length changes of mortar bars with lithium salt added as the effect of ASR}

The alkali value of the cement used in the experiment was $0.90 \%$, and its properties are given in table 3 . The readings of chronological changes were recorded on the $2 \mathrm{nd}$, 7 th and 14th days. The length changes in mortar bars with lithium additives at day 2, 7 and 14 are shown in figures 1,2 and 3, respectively.

The length changes at day two (figure 1) demonstrate that the length changes in the lithium-added specimens at day two were significantly lower than the respective values of the reference specimens ( $0 \%$ additive). Among the specimens with lithium additives, mortar bars with $\mathrm{LiNO}_{3}$ had relatively smaller length changes. The maximum length change rate was measured in the reference mortar bars $(0.060 \%)$, which had no additive. On the other hand, the minimum length change was measured in the mortar bars with $\mathrm{LiNO}_{3}$ additive $(0.009 \%)$, which had $3 \%$ additive. According to the second-day length change values, $\mathrm{LiNO}_{3}$ additive was more effective in reducing the length change.

The seven-day length change ratios displayed in figure 2 manifest that $0.121 \%$ maximum length change was observed in the reference mortar bar, whereas $0.016 \%$ minimum length change was observed in the mortar bars with $3 \% \mathrm{Li}_{2} \mathrm{CO}_{3}$ additive.

According to day-14 readings of length changes (figure 3$)$, the maximum length change $(0.335 \%)$ took place in the reference mortar bars while the minimum took place on $3 \% \mathrm{Li}_{2} \mathrm{CO}_{3}$-added mortar bars by $0.023 \%$.

For 14-day length changes, $0-0.1 \%$ are the length change limits for innocuous area according to ASTM C 1260-14. For the controlled zone (non-detrimental zone), these limits are $0.1-0.2 \%$. The length change measurements exceeding $0.2 \%$ indicate detrimental zone in the way of ASR.

A comparison of 14-day length changes according to ASTM C 1260-14 revealed that the length changes of reference mortar bars and mortar bars with $0.5-1.5 \% \mathrm{LiBr}$ added occurred in the detrimental zone. The length changes of mortar bars with $0.5-2.5 \% \mathrm{Li}_{2} \mathrm{SO}_{4}, 0.5-1.0 \% \mathrm{LiNO}_{3}$ and $2-3 \% \mathrm{LiBr}$ added took place in the controlled zone (detrimental non-detrimental zone). The length changes of mortar bars with the following additives occurred in the non-harmful zone: $2.5 \% \mathrm{Li}_{2} \mathrm{SO}_{4}, 1.5-3 \% \mathrm{LiNO}_{3}, 0.5-3.0 \%$ $\mathrm{Li}_{2} \mathrm{CO}_{3}$ and $0.5-3.0 \% \mathrm{LiF}$.

Considering the overall length change of mortars, it appears that the use of $0.5-2.5 \% \mathrm{Li}_{2} \mathrm{SO}_{4}, 0.5-1.0 \% \mathrm{LiNO}_{3}$ and $2-3 \% \mathrm{LiBr}$ additives among the lithium additives is the most appropriate.

\subsection{The microstructural properties of lithium- added mortar bars subjected to ASR effect}

Specimens extracted from different points on the mortar bars were prepared for microstructure analysis. Among the specimens obtained from mortar bars, the most suitable ones were selected in terms of surface and size properties. To carry out the microstructure surface inspection, these specimens were subjected to gold coating with the sputter coater. All the SEM pictures were taken in secondary electron mode on fracture surfaces. The specimens were examined by SEM. For the microstructure analysis, JSM 5600 SEM was used.

The SEM images and micro-structural features of reference mortar bars (no additive), in which the minimum length change was recorded, and of those with $3 \%$ lithium additive were evaluated.

SEM images pointed to the fact that ASR products generally formed in voids, in aggregate cracks and between aggregate and cement [1]. The expansive pressure appears to break the aggregate and form some new and relatively sharper cracks $[32,33]$. ASR gel induces pressure in the aggregate and in the cement paste, leading to stresses and thus cracking [34]. Dense ASR products with different morphologies were clearly seen in the images at approximately $100 \times$ magnification. Map cracking and gel seen in SEM images bring to sight the existence of ASR. These voids are thought to have formed as a result of the 


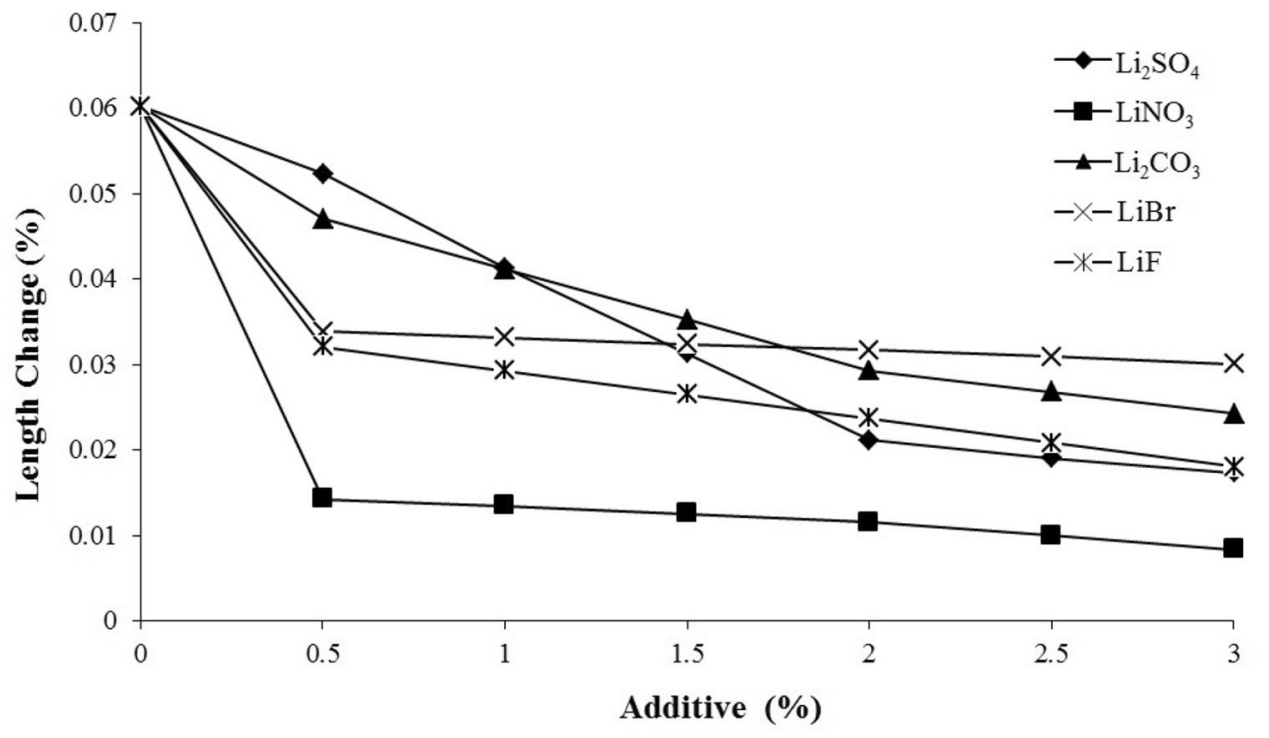

Figure 1. Length change at 2 days in mortar bars with lithium additives.

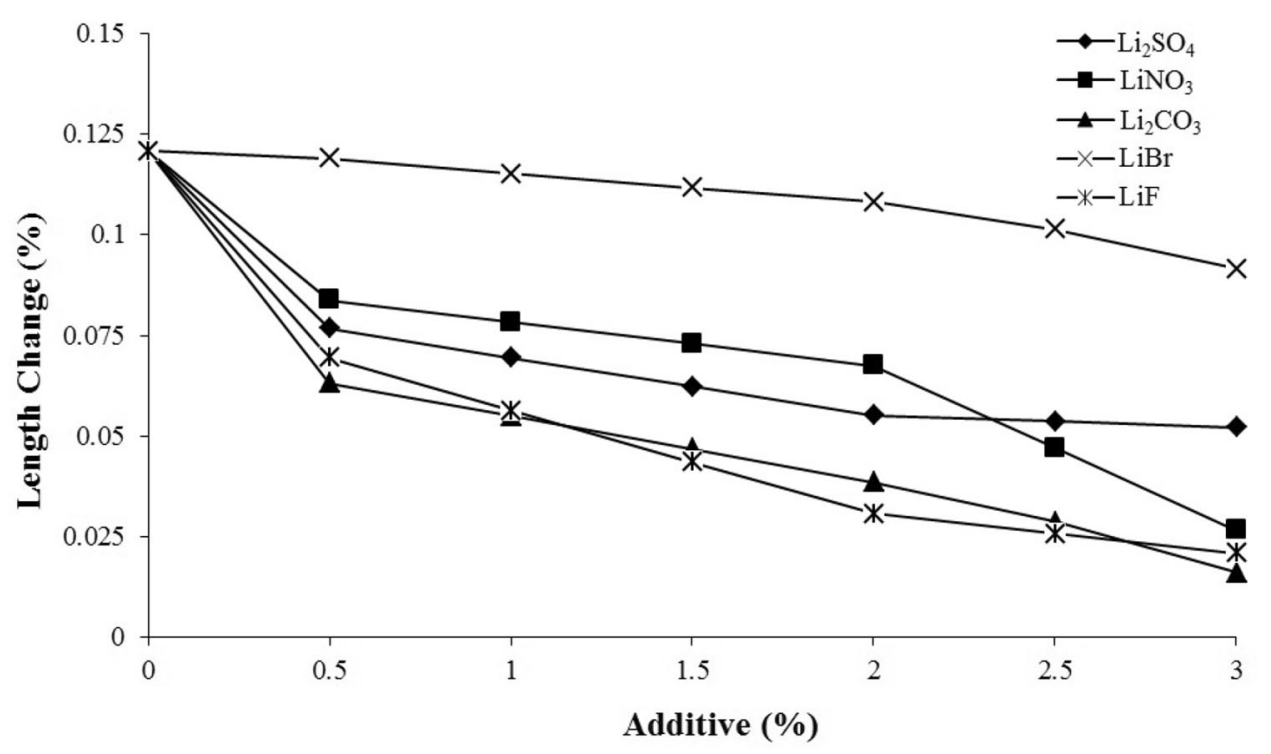

Figure 2. Length change at 7 days in mortar bars with lithium additives.

expansion of gel. The ASR products analysed generally formed in and around aggregate cracks [1].

As shown in figure 4, ASR products were widely observed in the reference mortar bars. ASR cracks generally formed with the formation of the shrinkage. They commonly started in the porous structure. The cracks and voids caused by ASR expansion are seen in the images at $35 \times$ and $650 \times$ magnifications. In the $650 \times$ magnification, ASR occurred in the form of shrinkage cracks.

As can be seen in figure $4 a$ and $b$, voids with sizes of 5 and $500 \mu \mathrm{m}$, which are in the form of map cracks caused by small sand particles, developed on the surface of mortars.
The map cracks and gel in the holes made the presence of ASR explicit. It can be inferred that these voids form because of gel expansion.

The SEM images of reference mortar bars obtained at the end of 14 days indicated that the width of ASR cracks reached $5 \mu \mathrm{m}$ in reference specimens. ASR cracks commonly formed in areas of voids and generally at sizes of 1-2 $\mu \mathrm{m}$ (figure $5 \mathrm{a}-\mathrm{c}$ ).

At 35-15000 $\times$ magnification, the massive product with diameters of 400 and $500 \mu \mathrm{m}$ started as splitting, small voids and had a destructive effect on aggregate (figure 5a 


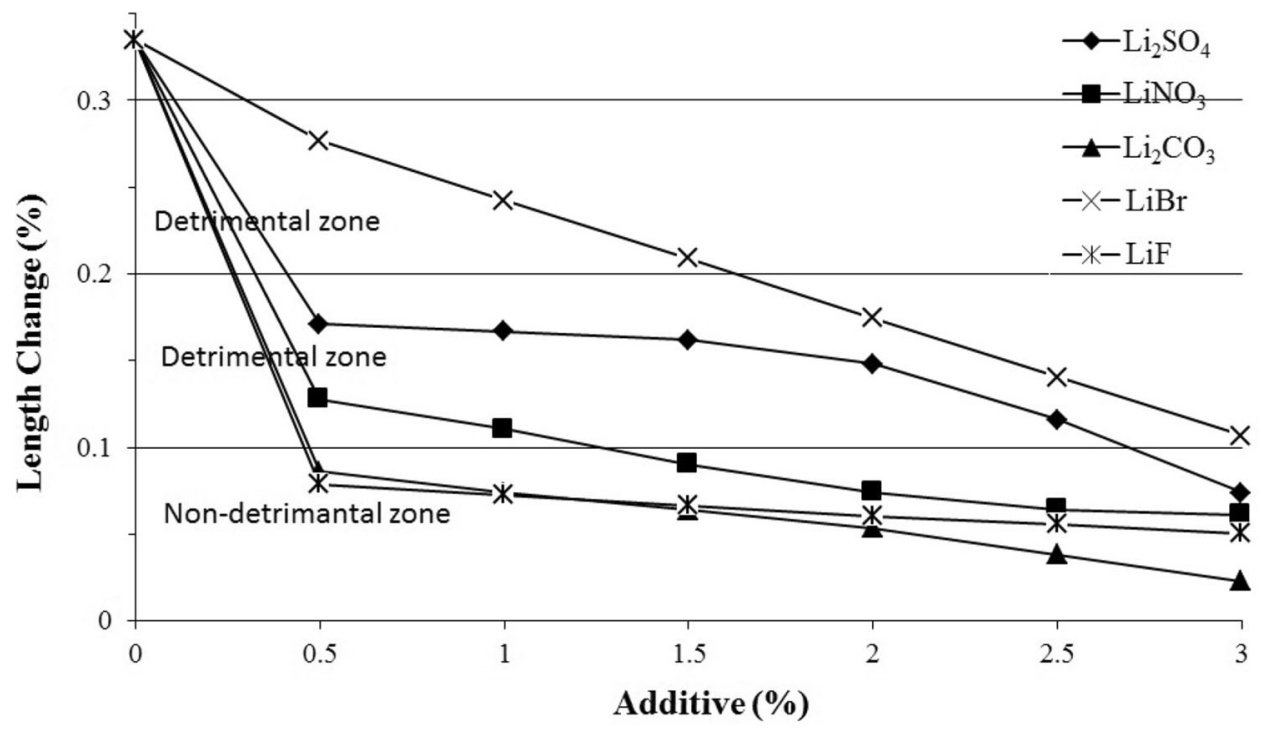

Figure 3. Length change at 14 days in mortar bars with lithium additives.

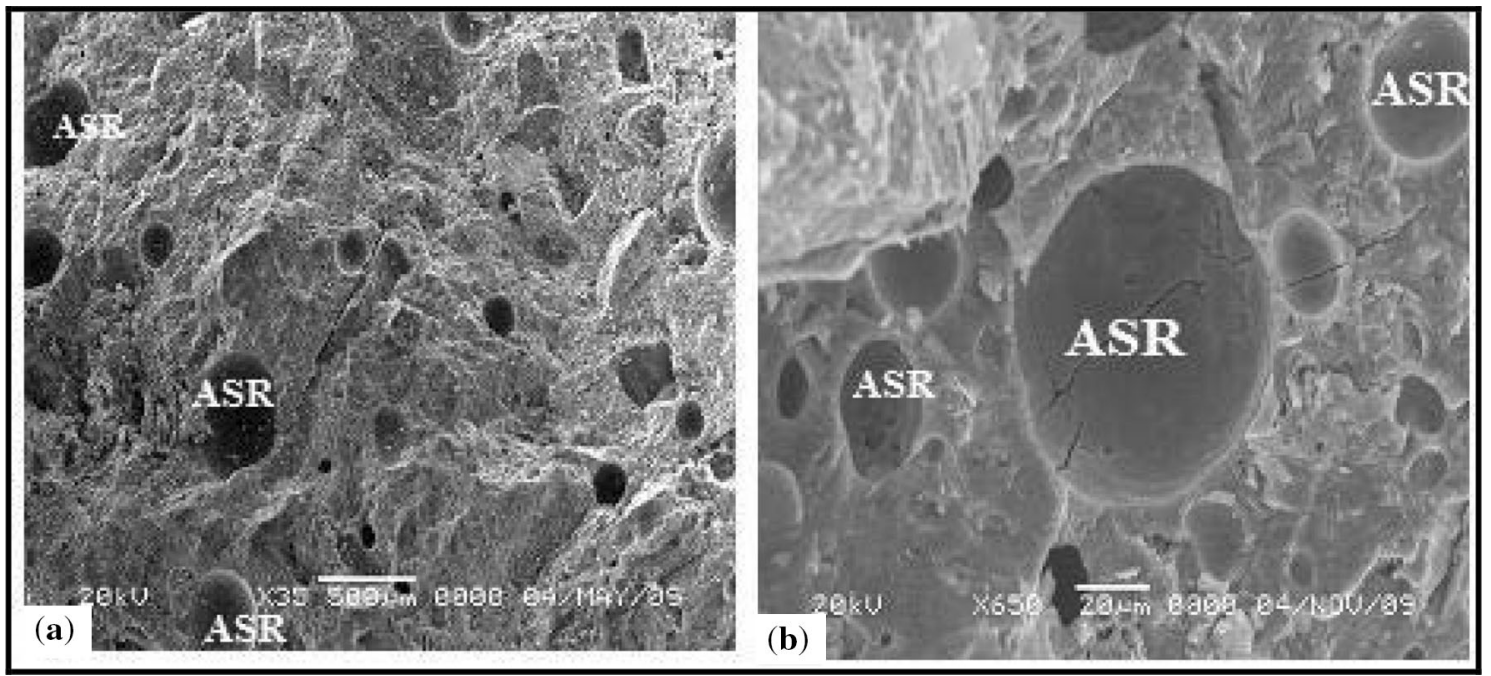

Figure 4. Image of reference samples at (a) $35 \times$ and (b) $650 \times$ magnification.

and b). At $15000 \times$ magnification, ASR appeared as a popcorn in reference mortars (figure $5 \mathrm{c}$ ).

The SEM analysis of specimens with $3 \% \mathrm{LiBr}$ added were subjected to ASR effect for 14 days; they showed that the crack widths were $3 \mu \mathrm{m}$ or smaller (figure $6 \mathrm{a}$ and $\mathrm{b}$ ). It was observed that the ASR effect decreased with increasing $\mathrm{LiBr}$ additive ratio. The SEM image of the reference samples at $900 \times$ magnification revealed ASR to a considerable extent. ASR tended to be lower as the quantity of $\mathrm{LiBr}$ additive increased (figure 6a). Products of ASR generally formed in and around the aggregate cracks in samples with $3 \% \mathrm{LiBr}$ additive (figure $6 \mathrm{~b}$ ). Moreover, the SEM analysis of reaction products was conducted (figure 6b), which manifested that, in the mortar bars with $3 \% \mathrm{LiBr}$ added, a significant web-shaped protective layer formed on the surface of aggregate and cement paste. ASR was rare in specimens with $3 \% \mathrm{LiBr}$ added and the biggest crack size was $3.5 \mu \mathrm{m}$.

The SEM analysis (figure 7a and b) of samples with $3 \%$ $\mathrm{Li}_{2} \mathrm{CO}_{3}$ added, subjected to ASR for 14 days, manifested that ASR products were less frequently observed in these samples compared with the reference (no additive) specimens. The cracks were as wide as, or below, $3 \mu \mathrm{m}$. The greater the $\mathrm{Li}_{2} \mathrm{CO}_{3}$ additive ratio, the fewer the ASR products (figure 7a). The ASR products generally developed inside the voids in the form of cracks (figure $7 b$ ). 


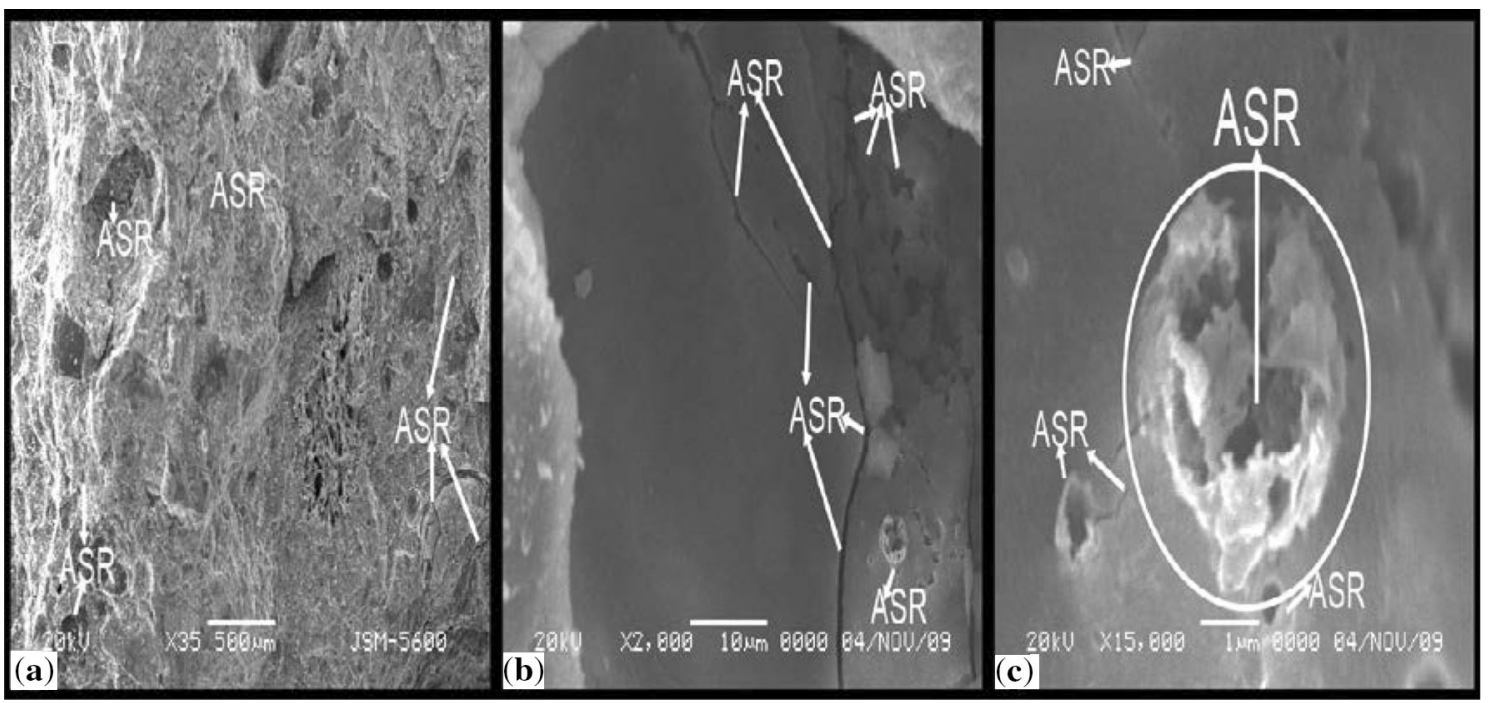

Figure 5. Images of reference samples at (a) $35 \times$, (b) $2000 \times$ and (c) $15000 \times$ magnification.

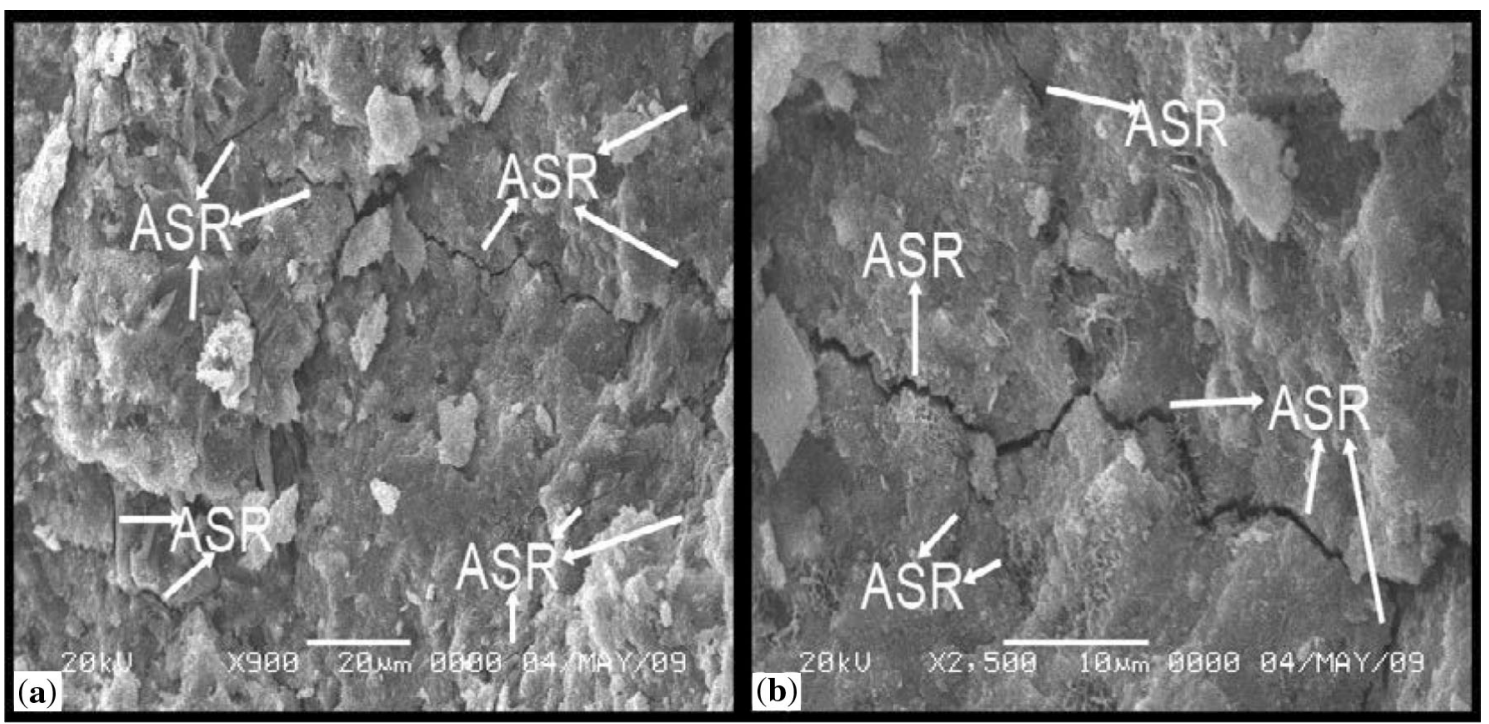

Figure 6. Image of samples with $3 \% \mathrm{LiBr}$ added at (a) $900 \times$ and (b) $2500 \times$ magnification.

Unlike the other lithium-added mortars, gel formation was observed around the ASR cracks. Zones where ASR was observed were in the form of round voids with widths up to $1000 \mu \mathrm{m}$. ASR cracks are seen inside these voids (figure 7a and $b$ ).

In the SEM images of samples with $3 \% \mathrm{LiNO}_{3}$ added, subjected to ASR for 14 days, ASR products appeared as map cracks in small voids. Compared with the reference specimens, fewer ASR products formed in specimens with $3 \% \mathrm{LiNO}_{3}$ (figure $8 \mathrm{a}$ ). The widths of ASR cracks were measured to be $3 \mu \mathrm{m}$ or smaller (figure $8 \mathrm{~b}$ ). As the $\mathrm{LiNO}_{3}$ additive ratio increased, the formation of ASR products decreased (figure 8a). ASR cracks in specimens with $3 \%$
$\mathrm{LiNO}_{3}$ added were in the form of round voids with sizes up to $200 \mu \mathrm{m}$ (figure $8 \mathrm{~b}$ ).

In the SEM images at $300 \times$ magnification, fewer ASR products were identified in reference (no additive) specimens than in specimens with $3 \% \mathrm{LiF}$ added and exposed to ASR for 14 days (figure 9a). The crack sizes were measured to be $2 \mu \mathrm{m}$ or below (figure $9 \mathrm{~b}$ ). As the LiF additive ratio increased, the ASR expansion decreased (figure 9a). In samples with $3 \% \mathrm{LiF}$ added, ASR cracks progressed in the form of round voids with sizes reaching $150 \mu \mathrm{m}$ (figure 9a).

SEM images of samples with $3 \% \mathrm{Li}_{2} \mathrm{SO}_{4}$ added $(100 \times$ magnified) subjected to ASR for 14 days demonstrated that 


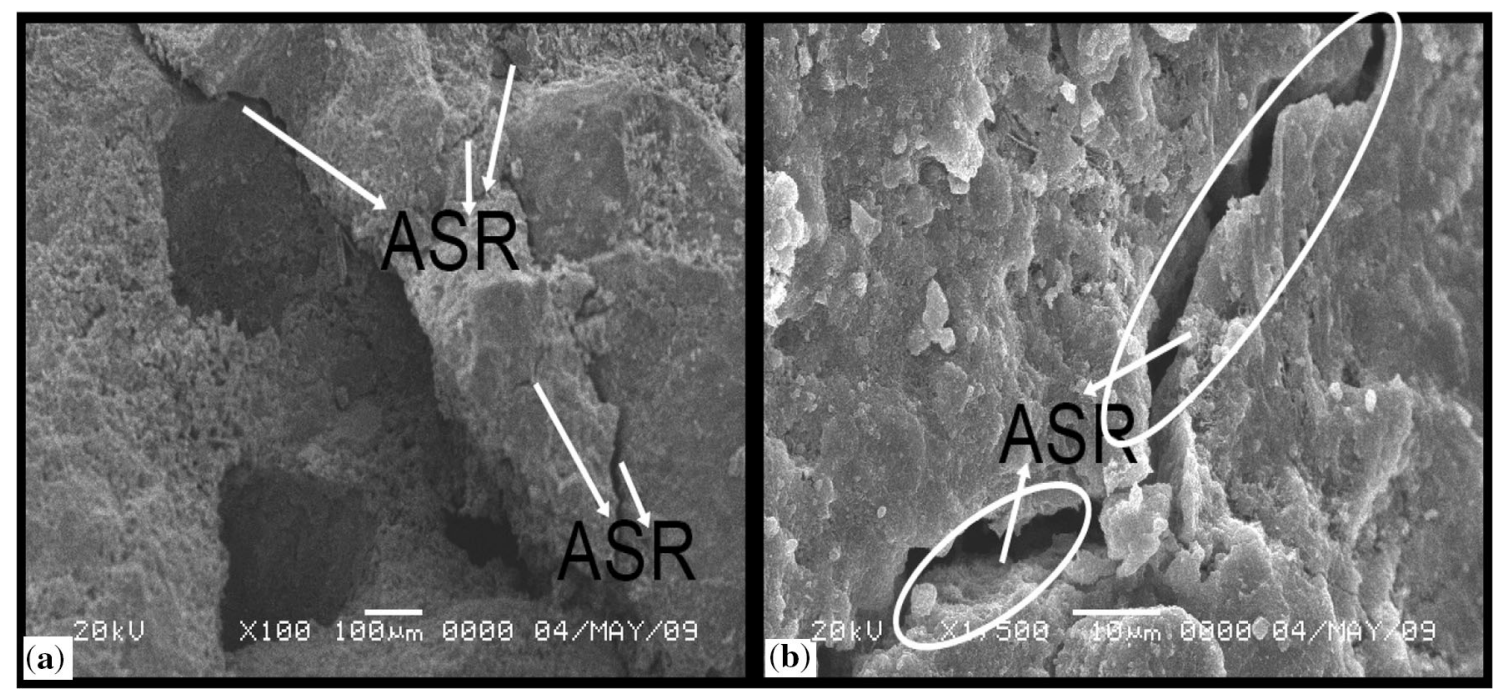

Figure 7. Image of samples with $3 \% \mathrm{Li}_{2} \mathrm{CO}_{3}$ added at (a) $100 \times$ and (b) $1500 \times$ magnification.

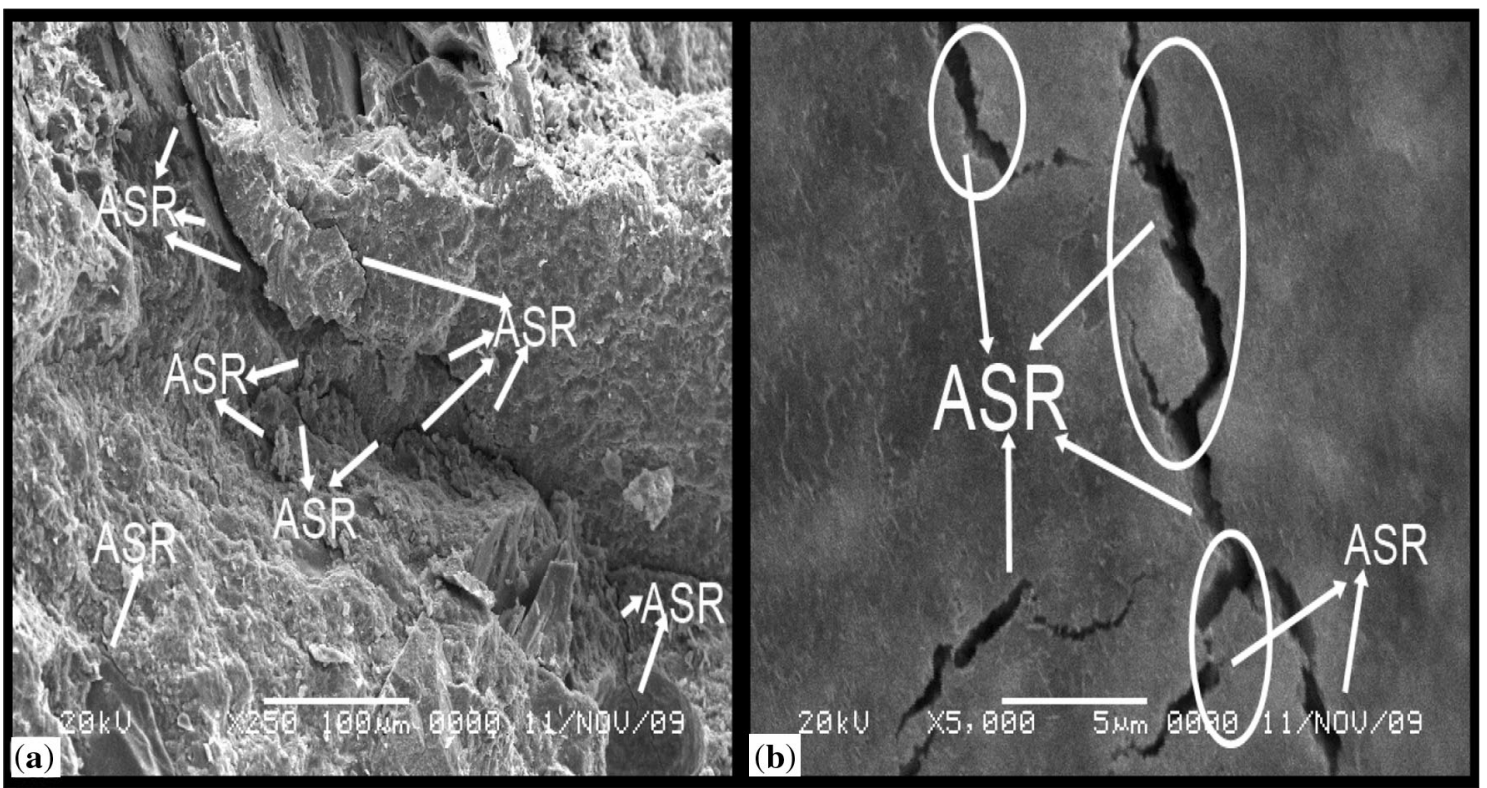

Figure 8. Image of samples with $3 \% \mathrm{LiNO}_{3}$ added at (a) $250 \times$ and (b) $5000 \times$ magnification.

fewer ASR products developed than in specimens with no additives (figure 10a). Crack widths measured were $2 \mu \mathrm{m}$ and smaller (figure 10b). It was found out that, as the $\mathrm{Li}_{2-}$ $\mathrm{SO}_{4}$ additive ratio increased, ASR development decreased (figure 10a). In specimens with $3 \% \mathrm{Li}_{2} \mathrm{SO}_{4}$ added, ASR cracks were in the form of round voids at sizes reaching $450 \mu \mathrm{m}$ (figure 10a).

The ASR was usually in the form of fractures and shrinkage cracks during the SEM study. Usually in a porous structure, cracks start and spread around the voids; $35 \times$ and $250 \times$ magnifications show the porous structures of the ASR. After 500 $\times$ magnification, intensive ASR products cause shrinkage cracks. A $5000 \times$ magnification image showed ASR products in the form of acicular gels between the aggregates and the cement paste.

The crack map in the SEM image and the gel reveal the presence of ASR. These voids are thought to be formed because of expansion of gel. The ASR products usually formed in and around aggregate cracks.

The EDS analyses of reference mortar and mortars including lithium additive subjected to ASR for 14 days are presented in table 4.

The EDS analysis of reference mortars subjected to ASR effect for 14 days yielded a high $\mathrm{CaO}$ ratio, and $\mathrm{SiO}_{2}$ ratio. 


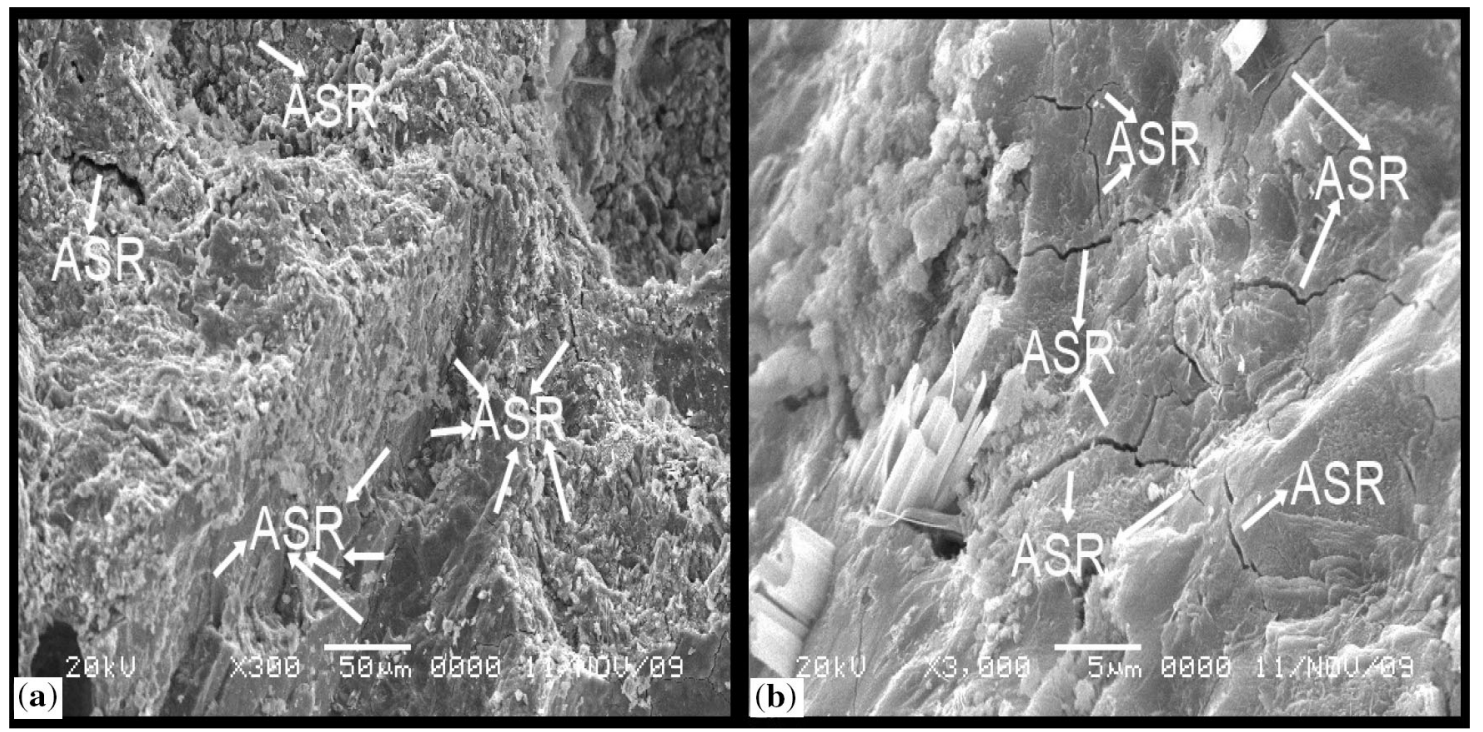

Figure 9. Image of samples with $3 \% \mathrm{LiF}$ added at (a) $300 \times$ and (b) $3000 \times$ magnification.

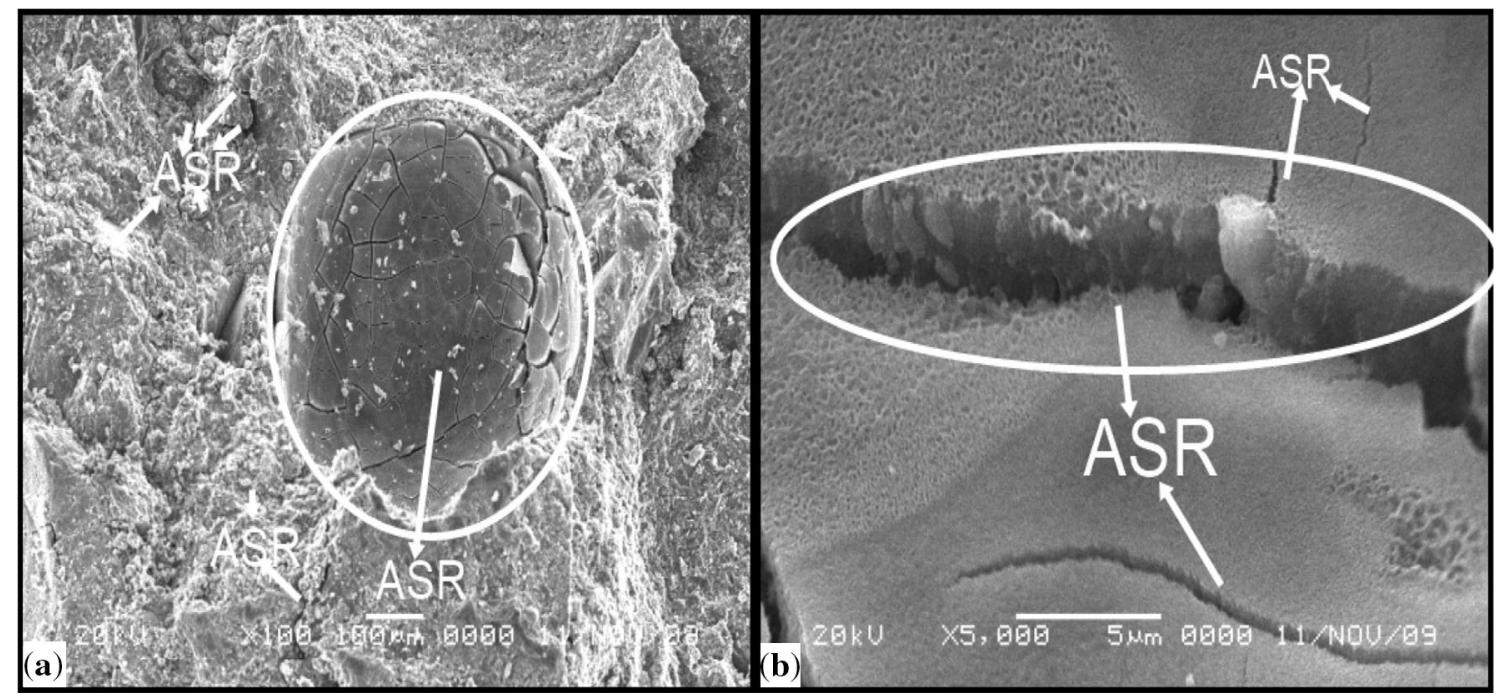

Figure 10. Image of samples with $3 \% \mathrm{Li}_{2} \mathrm{SO}_{4}$ added at (a) $100 \times$ and (b) $5000 \times$ magnification.

Table 4. EDS analysis of reference, $\mathrm{Li}_{2} \mathrm{SO}_{4}, \mathrm{LiNO}_{3}, \mathrm{Li}_{2} \mathrm{CO}_{3}, \mathrm{LiBr}$ and $\mathrm{LiF}$ added specimens.

\begin{tabular}{|c|c|c|c|c|c|c|}
\hline Compound & Reference & $3 \% \mathrm{LiBr}$ & $3 \% \mathrm{Li}_{2} \mathrm{CO}_{3}$ & $3 \% \mathrm{LiNO}_{3}$ & $3 \% \mathrm{LiF}$ & $3 \% \mathrm{Li}_{2} \mathrm{SO}_{4}$ \\
\hline $\mathrm{CaO}(\%)$ & 65.1 & 24.1 & 35.0 & 36.7 & 51.1 & 48.3 \\
\hline $\mathrm{SiO}_{2}(\%)$ & 25.0 & 37.0 & 42.1 & 35.7 & 31.2 & 44.5 \\
\hline $\mathrm{MgO}(\%)$ & 0.7 & 0.8 & 0.7 & 7.1 & 0.3 & 0.23 \\
\hline $\mathrm{Na}_{2} \mathrm{O}(\%)$ & 2.0 & 1.7 & 5.1 & 2.5 & 3.8 & 2.9 \\
\hline $\mathrm{Al}_{2} \mathrm{O}_{3}(\%)$ & 3.6 & 24.8 & 9.1 & 10.6 & 11.1 & 2.0 \\
\hline $\mathrm{K}_{2} \mathrm{O}(\%)$ & 0.6 & 2.5 & 0.4 & 1.0 & 0.1 & 0.5 \\
\hline $\mathrm{Fe}_{2} \mathrm{O}_{3}(\%)$ & 2.96 & 9.1 & 7.6 & 6.4 & 2.4 & 1.5 \\
\hline
\end{tabular}


The $\mathrm{CaO}$ ratio was obtained as $65.1 \%, \mathrm{SiO}_{2}$ as $25.0 \%$, and other oxides as $9.9 \%$. The EDS analysis of 3\% $\mathrm{LiBr}$ mortars subjected to ASR effect for 14 days yielded a high $\mathrm{CaO}$ ratio, $\mathrm{SiO}_{2}$ ratio and $\mathrm{Al}_{2} \mathrm{O}_{3}$ ratio. The $\mathrm{CaO}$ ratio was obtained as $24.1 \%, \mathrm{SiO}_{2}$ as $37.0 \%, \mathrm{Al}_{2} \mathrm{O}_{3}$ as $24.8 \%$ and other oxides as $14.1 \%$. The EDS analysis of $3 \% \mathrm{Li}_{2} \mathrm{CO}_{3}$ mortars subjected to ASR effect for 14 days yielded a high $\mathrm{CaO}$ ratio, $\mathrm{SiO}_{2}$ ratio and $\mathrm{Al}_{2} \mathrm{O}_{3}$ ratio. The $\mathrm{CaO}$ ratio was obtained as $35.0 \%, \mathrm{SiO}_{2}$ as $42.1 \%, \mathrm{Al}_{2} \mathrm{O}_{3}$ as $9.1 \%$ and other oxides as $13.8 \%$. The following ratios were obtained in the EDS analysis of specimens with $3 \% \mathrm{LiNO}_{3}$ added, subjected to 14-day ASR effect: $\mathrm{CaO} 36.7 \%, \mathrm{SiO}_{2} 35.7 \%$, $\mathrm{MgO} 7.1 \%, \mathrm{Al}_{2} \mathrm{O}_{3} 10.6 \%, \mathrm{Fe}_{2} \mathrm{O}_{3} 6.4 \%$ and other oxides smaller than $4 \%$. The EDS analysis of $3 \% \mathrm{LiF}$ mortars subjected to ASR effect for 14 days yielded a high $\mathrm{CaO}$ ratio, $\mathrm{SiO}_{2}$ ratio and $\mathrm{Al}_{2} \mathrm{O}_{3}$ ratio. The $\mathrm{CaO}$ ratio was obtained as $51.1 \%, \mathrm{SiO}_{2}$ as $31.2 \%, \mathrm{Al}_{2} \mathrm{O}_{3}$ as $11.1 \%$ and other oxides as $6.6 \%$. The EDS analysis of $3 \% \mathrm{Li}_{2} \mathrm{SO}_{4}$ mortars subjected to ASR effect for 14 days yielded a high $\mathrm{CaO}$ ratio, and $\mathrm{SiO}_{2}$ ratio. The $\mathrm{CaO}$ ratio was obtained as $48.3 \%, \mathrm{SiO}_{2}$ as $44.5 \%$ and other oxides as $7.2 \%$. ASR products did not show chemically homogeneous structure in the EDS analysis.

According to the SEM and EDS studies, there are less cracks in samples with higher lithium additive ratio. EDS studies implemented in dense and dense areas of ASR cracks have shown that $\mathrm{CaO}$ and $\mathrm{SiO}_{2}$ ratios are higher than those of other oxides. Increasing the proportion of lithium additives decreased the formation of ASR products.

\section{Conclusions}

The present study pertains to the effects of various lithium additives $\left(\mathrm{Li}_{2} \mathrm{SO}_{4}, \mathrm{LiNO}_{3}, \mathrm{Li}_{2} \mathrm{CO}_{3}, \mathrm{LiBr}\right.$ and $\left.\mathrm{LiF}\right)$, added to the mixing water of the mortar mixture by different mass percentages of cement $(0 \%, 0.5 \%, 1 \%, 1.5 \%, 2 \%, 2.5 \%$ and $3 \%$ ), on the ASR expansion of mortar. The ASR expansions of the mortar bars at 2, 7 and 14 days were measured, the morphology of the specimens was analysed by SEM and their chemical composition determined with the help of XRF.

At 2, 7 and 14 days, the greatest ASR expansion values were recorded in reference mortar bars, i.e., without lithium additives. Considering the overall length change of mortars, it appears that the use of $0.5-2.5 \% \mathrm{Li}_{2} \mathrm{SO}_{4}, 0.5-1.0 \%$ $\mathrm{LiNO}_{3}$ and $2-3 \% \mathrm{LiBr}$ additives among the lithium additives is the most appropriate Increasing the lithium additive ratio (by the percentage ratio to the amount of cement) was found to decrease the length changes of the mortar bars. In SEM study, ASR developed usually in the form of shrinkage cracks. The map cracks and gel, which are present in the voids, make the presence of ASR explicit. It was concluded that the voids formed because of gel expansion. The ASR products that were studied usually formed in and around the aggregate cracks. EDS conducted in zones of intensive and wide ASR cracks demonstrated that $\mathrm{CaO}$ and $\mathrm{SiO}_{2}$ ratios were higher than those of other oxides. Five types of lithium compounds that were under examination $\left(\mathrm{Li}_{2} \mathrm{SO}_{4}, \mathrm{LiNO}_{3}, \mathrm{Li}_{2} \mathrm{CO}_{3}, \mathrm{LiBr}\right.$ and $\left.\mathrm{LiF}\right)$ were demonstrated to be effective in reducing ASR expansions that could form in concrete. It can be concluded that lithium-added mortars that permeate into innocuous area lead to the enclosure of alkali products.

To conclude, the optimum lithium additive amount for ASR length expansion changes according to the lithium component. Thus, for ASR, the optimum ratios are as follows: $3 \% \mathrm{Li}_{2} \mathrm{SO}_{4}, 1.5-3 \% \mathrm{LiNO}_{3}, 0.5-3 \% \mathrm{Li}_{2} \mathrm{CO}_{3}$ and 0.5-3\% LiF. However, for $\mathrm{LiBr}$, even an additive ratio of $3 \%$ could restrict its development into the controlled area. It is seen that ASR expansion of mortars is mainly affected by the type and additive ratio of $\mathrm{Li}_{2} \mathrm{SO}_{4}, \mathrm{LiNO}_{3}, \mathrm{Li}_{2} \mathrm{CO}_{3}, \mathrm{LiBr}$ and $\mathrm{LiF}$ additives. However, further investigations are needed to fully examine long-term expansion and mechanical properties in relation to the mechanism of control of mitigation by lithium salts.

$\begin{array}{ll}\text { Abbreviations } \\ \text { ASR } & \text { alkali-silica reaction } \\ \mathrm{EDS} & \text { electron dispersion spectroscopy } \\ \mathrm{Li}_{2} \mathrm{CO}_{3} & \text { lithium carbonate } \\ \mathrm{Li}_{2} \mathrm{SO}_{4} & \text { lithium sulphate } \\ \mathrm{LiBr} & \text { lithium bromide } \\ \mathrm{LiF} & \text { lithium fluoride } \\ \mathrm{LiNO}_{3} & \text { lithium nitrate } \\ \mathrm{LiOH} & \text { lithium hydroxide } \\ \mathrm{Na}{ }_{2} \mathrm{O} e q & \text { alkali equivalent } \\ \mathrm{NaOH} & \text { sodium hydroxide } \\ \mathrm{SEM} & \text { scanning electron microscopy } \\ \mathrm{XRD} & \text { X-ray diffraction } \\ \text { XRF } & \text { X-ray fluorescence spectrometry }\end{array}$

\section{References}

[1] Demir I and Arslan M 2013 The mechanical and microstructural properties of $\mathrm{Li}_{2} \mathrm{SO}_{4}, \mathrm{LiNO}_{3}, \mathrm{Li}_{2} \mathrm{CO}_{3}$ and $\mathrm{LiBr}$ added mortars exposed to alkali-silica reaction. Constr. Build. Mater. 42: 64-77

[2] Demir İ and Sevim Ö 2017 Effect of sulfate on cement mortars containing $\mathrm{Li}_{2} \mathrm{SO}_{4}, \mathrm{LiNO}_{3}, \mathrm{Li}_{2} \mathrm{CO}_{3}$ and $\mathrm{LiBr}$. Constr. Build. Mater. 156: 46-55

[3] Stanton T E 2008 Expansion of concrete through reaction between cement and aggregate. MI: Farmington Hills

[4] Frohnsdorff G, Clifton J R and Brown P W 1978 History and status of standards relating to alkalies in hydraulic cements. In: Cement Standards-Evolution and Trends. West Conshohocken, PA: ASTM International 
[5] Hobbs D W 1988 Alkali-silica reaction in concrete. Michigan: Thomas Telford Publishing

[6] Diamond S and Penko M 1992 Alkali-silica reaction processes: the conversion of cement alkalies to alkali hydroxide. In: Proceedings of the Symposium on Durability of Concrete ACI SP131, American Concrete Institute, vol. 131, pp. 153-168

[7] Helmuth R, Stark D, Diamond S and Moranville-Regourd M 1993 Alkali-silica reactivity: an overview of research. Washington, DC: National Research Council

[8] Capra B and Bournazel J P 1995 Perspectives nouvelles pour la prise en compte des alcali-réactions dans le calcul des structures. Mater. Struct. 28(2): 71-73

[9] Taylor G D 2014 Materials in construction: an introduction. UK: Taylor \& Francis

[10] Ineson P R 1990 Siliceous components in aggregates. Cem. Concr. Compos. 12(3): 185-190

[11] Wen H X 1998 Alkali-aggregate reaction in concrete. Lecture Notes. Hong Kong: Civil Engineering Department, Hong Kong University, pp. 1-55

[12] Bagel L 1998 Strength and pore structure of ternary blended cement mortars containing blast furnace slag and silica fume. Cem. Concr. Res. 28(7): 1011-1022

[13] Dongxue L, Xinhua F, Xuequan W and Mingshu T 1997 Durability study of steel slag cement. Cem. Concr. Res. 27(7): 983-987

[14] Monteiro P J M, Wang K, Sposito G, Dos Santos M C and de Andrade W P 1997 Influence of mineral admixtures on the alkali-aggregate reaction. Cem. Concr. Res. 27(12): 1899-1909

[15] Ramlochan T, Thomas M and Gruber K A 2000 The effect of metakaolin on alkali-silica reaction in concrete. Cem. Concr. Res. 30(3): 339-344

[16] Malvar L J, Cline G D, Burke D F, Rollings R, Sherman T W and Greene J L 2002 Alkali-silica reaction mitigation: state of the art and recommendations. ACI Mater. J. 99(5): 480-489

[17] Mazarei V, Trejo D, Ideker J H and Isgor O B 2017 Synergistic effects of ASR and fly ash on the corrosion characteristics of RC systems. Constr. Build. Mater. 153: 647-655

[18] Souza L M, Polder R B and Çopuroğlu O 2017 Lithium migration in a two-chamber set-up as treatment against expansion due to alkali-silica reaction. Constr. Build. Mater. 134: 324-335

[19] Leemann A, Bernard L, Alahrache S and Winnefeld F 2015 ASR prevention-effect of aluminum and lithium ions on the reaction products. Cem. Concr. Res. 76: 192-201

[20] Ekolu S, Rakgosi G and Hooton D 2017 Long-term mitigating effect of lithium nitrate on delayed ettringite formation and ASR in concrete-microscopic analysis. Mater. Charact. 133: 165-175
[21] Islam M S and Ghafoori N 2016 Experimental study and empirical modeling of lithium nitrate for alkali-silica reactivity. Constr. Build. Mater. 121: 717-726

[22] Aquino W, Lange D A and Olek J 2001 The influence of metakaolin and silica fume on the chemistry of alkali-silica reaction products. Cem. Concr. Compos. 23(6): 485-493

[23] Juenger M C G and Ostertag C P 2004 Alkali-silica reactivity of large silica fume-derived particles. Cem. Concr. Res. 34(8): 1389-1402

[24] Ueda T, Baba Y and Nanasawa A 2013 Penetration of lithium into ASR-affected concrete due to electro-osmosis of lithium carbonate solution. Constr. Build. Mater. 39: 113-118

[25] Feng X, Thomas M D A, Bremner T W, Folliard K J and Fournier B 2010 New observations on the mechanism of lithium nitrate against alkali silica reaction (ASR). Cem. Concr. Res. 40(1): 94-101

[26] Kim T and Olek J 2016 The effects of lithium ions on chemical sequence of alkali-silica reaction. Cem. Concr. Res. 79: 159-168

[27] Leemann A, Lörtscher L, Bernard L, Le Saout G, Lothenbach B and Espinosa-Marzal R M 2014 Mitigation of ASR by the use of $\mathrm{LiNO}_{3}$-characterization of the reaction products. Cem. Concr. Res. 59: 73-86

[28] Stark D, Morgan B and Okamoto P 1993 Eliminating or minimizing alkali-silica reactivity. Washington, DC: National Research Council

[29] Diamond S and Ong S 1992 The mechanisms of lithium effects on ASR. In: Proceedings of the 9th International Conference on Alkali-Aggregate Reaction. London: Concrete Society of UK, pp. 269-278

[30] Mo X 2005 Laboratory study of LiOH in inhibiting alkalisilica reaction at $20^{\circ} \mathrm{C}$ : a contribution. Cem. Concr. Res. 35(3): 499-504

[31] ASTM C1260-14 2014 Standard test method for potential alkali reactivity of aggregates (mortar-bar method), American Society of Testing and Materials. West Conshohocken, PA: ASTM International

[32] Gautam B P and Panesar D K 2017 The effect of elevated conditioning temperature on the ASR expansion, cracking and properties of reactive Spratt aggregate concrete. Constr. Build. Mater. 140: 310-320

[33] Morenon P, Multon S, Sellier A, Grimal E, Hamon F and Bourdarot E 2017 Impact of stresses and restraints on ASR expansion. Constr. Build. Mater. 140: 58-74

[34] Li B, Baingam L, Kurumisawa K, Nawa T and XiaoZhou L 2018 Micro-mechanical modelling for the prediction of alkali-silica reaction (ASR) expansion: influence of curing temperature conditions. Constr. Build. Mater. 164: 554-569 